\title{
Metal Distribution in the Environmental Compartments of Manguaba Lagoon (Alagoas State, Brazil)
}

\author{
Emerson S. Freire, ${ }^{a}$ Alinne D. P. Wanderley, ${ }^{a}$ Wander G. Botero ${ }^{a}$ and Daniela S. Anunciação ${ }^{\oplus *, a}$ \\ ${ }^{a}$ Instituto de Química e Biotecnologia, Universidade Federal de Alagoas, Campus A. C. Simões, \\ 57072-900 Maceió-AL, Brazil
}

\begin{abstract}
The metal concentrations in water, sediments and mollusks (Tagelus plebeius) of the Manguaba Lagoon and the influence of humic substances from water and sediments in the distribution of these metals were investigated in this work. The mean metal concentrations in water were: $\mathrm{Mg}(89.0 \pm 0.11), \mathrm{Ca}(32.0 \pm 0.10), \mathrm{Fe}(0.97 \pm 0.02), \mathrm{Mn}(0.52 \pm 0.01), \mathrm{Zn}(0.33 \pm 0.10)$ and $\mathrm{Pb}(0.22 \pm 0.02) \mathrm{mg} \mathrm{L}^{-1}$. The $\mathrm{Pb}$ concentrations were above the Brazilian legislation limit. All sediment data were below maximum limit established by the National Council for the Environment (CONAMA, Brazil) of the Ministry of the Environment, and the concentration ranges for metals were: $\mathrm{Fe}$ (1199-60000), $\mathrm{Mg}$ (339-8870), Ca (461-3838), Cr (<LOQ-39.5) and $\mathrm{Pb}(<\mathrm{LOQ}-12.5) \mathrm{mg} \mathrm{kg}^{-1}$ (LOQ: limit of quantification). None of the principal contaminants $(\mathrm{Cr}, \mathrm{Pb}$ and $\mathrm{Cd}$ ) was determined in Tagelus plebeius, being a positive fact once the population nearby Manguaba Lagoon consumes large amounts of this mollusk. According to the results, the influence of humic substances in the contaminant retention is evident as they become unavailable for absorption by mollusks of Manguaba Lagoon.
\end{abstract}

Keywords: metals, water, sediment, biota, estuary, humic substances

\section{Introduction}

The economic, social and technological developments have resulted in a considerable increase of environmental pollutants, compromising aquatic and terrestrial systems. ${ }^{1}$ Among many pollutants, potentially toxic metals (PTMs) are some of the most significant since they belong to a category of compounds with wide applicability and toxicity that cannot be chemically or biologically degraded in the environment or living organisms. ${ }^{2,3}$ This concept is dependent of the environmental matrix concentration, once in appropriate levels, metals like $\mathrm{Ca}, \mathrm{Fe}, \mathrm{Mn}, \mathrm{Mo}$ and $\mathrm{Zn}$ (focus of the present work) are considered as nutrients. On the other side, the presence of metallic species in the environment, such as $\mathrm{Pb}, \mathrm{Cd}$ and $\mathrm{Cr}$, is of concern as they are harmful to life even at low concentrations. ${ }^{4,5}$ Among the adverse health problems related to these metals, cadmium is mainly accumulated in kidney and liver, and induces reactive oxygen species (ROS) production resulting in oxidative stress. ${ }^{6}$ Although trivalent chromium is present in many foods and supplementation products, it can naturally be converted into the hexavalent form, a potent carcinogenic that induces cellular damage

*e-mail: daniela.anunciacao@iqb.ufal.br and adverse health effects by multifront mechanism of action. ${ }^{7}$ Regarding to the exposure and oral intake of lead, it may disturb physiological functions. ${ }^{8}$ Children are more affected by gastrointestinal absorption of lead, and in adults, the cardiovascular and renal systems are the most critically affected. ${ }^{9}$ It must be also considered that lead is deposited in bone tissue and its half-life can reach 30 years. ${ }^{10}$

PTMs present in the environment interact with natural organic matter (NOM) influencing in the mobility, degradation, transport and availability of these contaminants in the environment. ${ }^{11}$

The principal components of NOM are the humic substances (HS) which belong to a class of compounds without any generical identity and contain several functional groups in their structures which give them an outstanding complexing capacity with chemical species like PTM. ${ }^{12,13}$ The structural characteristics and affinity with contaminants are essentially dependent of climatic conditions and the species present in the environment during the decomposition process of vegetal and animal residues. Therefore, each environment must be investigated in order to evaluate the characteristics of NOM present in waters and sediments and their influence in the availability of contaminants to this environment. ${ }^{12}$ 
The Mundaú-Manguaba Estuarine-Lagoon system (MMELS) is a representative ecosystem of Alagoas State coast and has a socioeconomic significative importance to this state, mostly to the capital Maceió. The system is formed by Mundaú River which drains in the lagoon of the same name and by Paraíba do Meio and Sumaúma rivers, which drain in the Manguaba Lagoon. ${ }^{14}$

Estuaries like MMELS are among regions of major productive development and provide an important mean of life for inhabitants that live surrounding and take almost all their sustenance from this ecosystem. However, despite the importance that these ecosystems plays for human populations and several species of organisms which depend on them, MMELS has been impacted by anthropic activities becoming receptor of domestic and industrial effluents resulting in changes in its balance. ${ }^{14-16}$ Among the main anthropic activities, the wastewater discharges, improper disposal of solid residues, silting, eutrophication, discharge of untreated industrial effluents, disordered occupation of the MMELS area, inadequate farming and fishing practices, low involvement and social engagement in the management of the estuarine complex stand out. ${ }^{14,16,17}$

These actions compromise public health because of the appearance of hydric diseases and also touristic activities in the region. The disorganized fishing exploitation leads to socioeconomic consequences as well as environmental problems due to residues disposal from industry and from local inhabitants. ${ }^{17}$

One of the main activities in MMELS is fishing, with emphasis on "sururu" (Mytella charruana) as this specie is related to a high commercial value for gastronomy and local tourism, and the Tagelus plebeius popularly known as "unha-de-velho". This bivalve, from the Solecurtidae family, does not have aggregated commercial value and lives in sanding regions at the bay margins. ${ }^{18,19}$ It has a significant occurrence in the region, and because of the facility in fishing, it is widely consumed by local population, mainly by fishers, characterizing a concern about chemical composition and contamination of this food. ${ }^{18}$

Thus, the goal of this study was to characterize Manguaba Lagoon which integrates the MMELS on a basis of total concentrations of potentially toxic metals in water, sediment and biota (Tagelus plebeius) and to verify the influence of humic substances from waters and sediment in the availability of these metals for this ecosystem.

\section{Experimental}

Reagents and solutions

All reagents used were of analytical grade. Acid solutions were prepared by dilution of $\mathrm{HNO}_{3}\left(65 \% \mathrm{v} \mathrm{v}^{-1}\right)$ Suprapure ${ }^{\circledast}$ with ultrapure water from a Milli-Q system (Millipore, California, USA). They were also used $\mathrm{H}_{2} \mathrm{O}_{2}\left(30 \% \mathrm{v} \mathrm{v}^{-1}\right)$, concentrated $\mathrm{HCl}\left(37 \% \mathrm{v} \mathrm{v}^{-1}\right), \mathrm{HF}\left(48 \% \mathrm{v} \mathrm{v}^{-1}\right)$ and $\mathrm{H}_{3} \mathrm{BO}_{3}$ $\left(100 \%, \mathrm{~m} \mathrm{~m}^{-1}\right)$. Standard solutions of the chemical elements were prepared by dilution of commercial stock solutions of $1000 \mathrm{mg} \mathrm{L}^{-1}$ (Merck, São Paulo, Brazil).

\section{Sampling}

Samplings were carried out in May 2016 (before the rainy season) at low tide. Superficial water samples were collected in the lagoon in decontaminated polyethylene bottles, and the physico-chemical parameters ( $\mathrm{pH}$, hardness, chloride and total organic carbon (TOC)) were determined in the laboratory and published in a previous work developed by our group. ${ }^{16}$ These physico-chemical parameters were used as comparative reference in the present work. For determination of total metal concentrations, a set of the same water samples was filtered, acidified with $0.1 \mathrm{~mol} \mathrm{~L}^{-1} \mathrm{HCl}$ and stored under refrigeration till extraction procedures for spectrometric analysis performed within three months after sampling. ${ }^{20}$

Sampling of superficial sediment was performed in the same collecting points of water whose characteristics are described in Table 1 and Figure 1. Sediments were collected with a polyethylene spreader and stored in hermetical plastic bags under refrigeration till sample treatment and spectrometric analysis steps. ${ }^{20}$

The Tagelus plebeius mollusks were collected by hand in the superficial sediment, at the same sampling points of water and sediment (Figure 1). Then, samples were stored in plastic bags and transported to the laboratory for treatment and analysis.

\section{Extraction of humic substances from waters and sediments}

The extraction of aquatic humic substances (AHS) was based on the procedure followed by most of the researchers associated to the International Humic Substances Society $(\text { IHSS })^{21}$ for pooled samples. For the extraction of AHS, $360 \mathrm{~L}$ of samples composed by surface waters from Manguaba Lagoon (TOC $=1.00 \pm 0.20 \mathrm{mg} \mathrm{L}^{-1}$ ) were used, and after extraction, the samples were lyophilized in an equipment model IS 3000 (Terroni, São Carlos, Brazil) and a pooled sample was obtained providing the characteristics of aquatic organic matter from the Manguaba Lagoon. ${ }^{16}$

Sediment samples were lyophilized, and for extraction of HS, a procedure for solid matter extraction of IHSS was used. For that, it was used $0.10 \mathrm{~mol} \mathrm{~L}^{-1} \mathrm{NaOH}$ as extractor, in the ratio $1: 10\left(\mathrm{~m} \mathrm{v}^{-1}\right)$ (sediment/extractor) at $25^{\circ} \mathrm{C}$, under stirring of $380 \mathrm{rpm}$ for $4 \mathrm{~h}$ in inert 
Table 1. Location and characteristics of sampling points at Manguaba Lagoon (Alagoas State, Brazil)

\begin{tabular}{|c|c|c|c|}
\hline Collecting point & Local of sampling & Coordinates & Characteristic \\
\hline Point 1 & near Marechal Deodoro City & $\begin{array}{l}-9.735427 \\
-35.883535\end{array}$ & low population density around \\
\hline Point 2 & near Marechal Deodoro City & $\begin{array}{l}-9.718042 \\
-35.891260\end{array}$ & restaurants nearby \\
\hline Point 3 & beyond Marechal Deodoro City & $\begin{array}{l}-9.710301 \\
-35.891689\end{array}$ & evidence of inappropriate disposal of liquid and solid residues \\
\hline Point 4 & opposite Marechal Deodoro City & $\begin{array}{l}-9.710471 \\
-35.876669\end{array}$ & $\begin{array}{l}\text { area with native vegetation, signs of deforestation and presence } \\
\text { of communities nearby }\end{array}$ \\
\hline Point 5 & near the Pau-Brasil River Drainage Channel & $\begin{array}{l}-9.726931 \\
-35.884675\end{array}$ & area $40 \mathrm{~m}$ far from the edge near river drainage channel \\
\hline Point 6 & near some islands & $\begin{array}{l}-9.732598 \\
-35.876171\end{array}$ & area with native vegetation \\
\hline Point 7 & Breião Stream & $\begin{array}{l}-9.736198 \\
-35.862635\end{array}$ & - \\
\hline
\end{tabular}

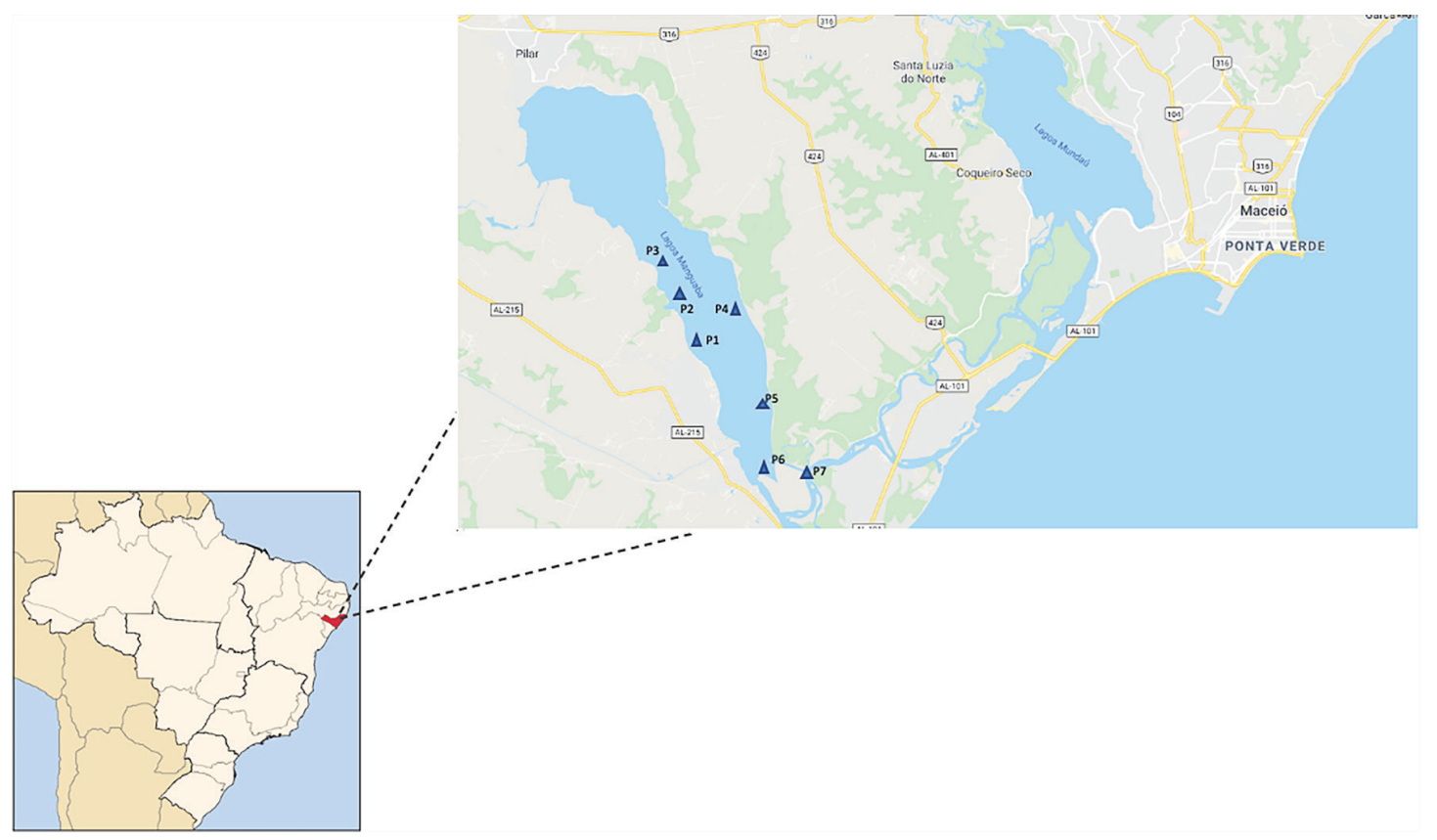

Figure 1. Sampling map with collecting points at Manguaba Lagoon (Alagoas State, Brazil). Source: Google maps adapted by the authors.

atmosphere. Subsequently, samples were centrifuged, and the supernatant, named sediment humic substances (SHS), were dried in an oven at $60{ }^{\circ} \mathrm{C} .{ }^{21}$

\section{Sample treatment}

Water samples were digested according to a procedure established in the literature. ${ }^{22}$ Briefly, $1.0 \mathrm{~mL}$ of $\mathrm{HNO}_{3}$ was added to $7.0 \mathrm{~mL}$ of sample, and the system was microwave digested according to the heating program described in Table 2. After that, the digested samples were completed with ultra pure water till a final volume of $20 \mathrm{~mL}$ for further spectrometric analysis to metals determination.
Samples of AHS, sediment, SHS and mollusk were submitted to total microwave assisted digestion established in the literature. ${ }^{23}$ For sediment, it was used $250 \mathrm{mg}$ of sample, $9.0 \mathrm{~mL}$ of $\mathrm{HNO}_{3}$ and $3.0 \mathrm{~mL}$ of HF. For mollusk, only $9 \mathrm{~mL}$ of $\mathrm{HNO}_{3}$ were used. After a pre-digestion step of $30 \mathrm{~min}$ in the chapel, flasks were sealed and the digestion was performed in a closed system according to the heating program expressed in Table 2.

After digestion, the system was cooled at room temperature $\left(25^{\circ} \mathrm{C}\right)$, it was added a solution of $\mathrm{H}_{3} \mathrm{BO}_{3}$ $(40 \%)$ to the flasks containing HS and sediment, and after filtration, the sample solutions were completed with ultra pure water till $100 \mathrm{~mL}$. 
Table 2. Heating program for microwave total digestion of environmental samples from Manguaba Lagoon

\begin{tabular}{lccc}
\hline \multicolumn{4}{c}{ Water } \\
\hline Step & time $/$ min & Temperature $/{ }^{\circ} \mathrm{C}$ & Power / W \\
\hline 1 & 20 & 180 & 400 \\
2 & 20 & 180 & 400 \\
3 & 20 & cooling & 0 \\
\hline \multicolumn{4}{c}{ AHS, SHS, sediment and mollusk } \\
\hline Step & time / min & Temperature $/{ }^{\circ} \mathrm{C}$ & Power / W \\
\hline 1 & 10 & 165 & 400 \\
2 & 10 & 170 & 400 \\
3 & 3 & cooling & 0 \\
\hline
\end{tabular}

AHS: aquatic humic substances; SHS: sediment humic substances.

\section{Metal determination by ICP OES}

For quantification of metals by inductively coupled plasma optical emission spectrometry (ICP OES), multielemental standard solutions were prepared in the range from 0 to $150 \mathrm{mg} \mathrm{L}^{-1}$ for macroelements $(\mathrm{Ca}(317.933 \mathrm{~nm})$ (ionic), Fe (238.204 nm) (ionic), $\operatorname{Mg}(285.213 \mathrm{~nm})$ (atomic), Mn (257.610 nm) (ionic), $\mathrm{Zn}(206.200 \mathrm{~nm})$ (ionic)); and from 0 to $2 \mathrm{mg} \mathrm{L}^{-1}$ for microelements ( $\mathrm{Cd}(226.502 \mathrm{~nm})$ (ionic), $\mathrm{Pb}(220.353 \mathrm{~nm})$ (ionic), Cr (267.716 nm) (ionic), Mo (202.031 nm) (ionic)). The analyses were performed in a PerkinElmer equipment, model Optima 7300DV (Waltham, USA) and the operational conditions are presented in Table 3.

Table 3. Operational conditions of ICP OES for environmental samples analyses

\begin{tabular}{lc}
\hline Parameter & Value \\
\hline Power RF / W & 1300 \\
Pump flow rate / $\left(\mathrm{L} \mathrm{min}^{-1}\right)$ & 0.0015 \\
Nebulizer gas flow / $\left(\mathrm{L} \mathrm{min}^{-1}\right)$ & 0.800 \\
Auxiliary gas flow / $\left(\mathrm{L} \mathrm{min}^{-1}\right)$ & 0.200 \\
Plasma gas flow / $\left(\mathrm{L} \mathrm{min}^{-1}\right)$ & 15.0 \\
View & axial \\
Nebulizer & Low Flow GernCone \\
Nebulizer chamber & cyclonic \\
\hline
\end{tabular}

ICP OES: inductively coupled plasma optical emission spectrometry; RF: radio frequency.

\section{Figures of merit}

All the analytical measurements were performed in triplicate. Regarding to the determination of LOQ (limit of quantification) for all metals, they were calculated from standard deviation (sd) of the intensity of signal of ten analytical blank solutions, according to the
International Union of Pure and Applied Chemistry (IUPAC) expression: ${ }^{24} \mathrm{LOQ}=10 \mathrm{sd} \mathrm{S}^{-1}$, where $\mathrm{S}$ is the sensitivity of the analytical curve.

The accuracy and precision of the method were evaluated using a standard reference material of estuarine sediment (SRM 1646a) from National Institute of Standards and Technology (NIST) (Gaithersburg, MD, USA) and a certified reference material of Green River Shale (SGR-1) from the United States Geological Survey (USGS) (Lakewood, Colorado, USA), for sediment samples. For mollusk, a standard reference material of oyster tissue (SRM 1566b) acquired from NIST was used

\section{Multivariate statistical analysis}

The statistical treatment of the experimental data related to the contents of metals and environmental samples evaluated was performed using the program Minitab ${ }^{25}$ for hierarchical cluster analysis (HCA) with data normalized by self-scaling and Euclidean distance.

\section{Results and Discussion}

\section{General features of Manguaba Lagoon}

The physico-chemical parameters of water samples from Manguaba Lagoon were previously published by our group in the first stage of this study. ${ }^{16}$ The mean $\mathrm{pH}$ value of 7.19 for the sampling points along the lagoon indicated that water had a neutral character according to the potability parameters established by National Council for the Environment (CONAMA, Brazil) of the Ministry of the Environment Resolution No. 357/2005 ${ }^{26}$ for brackish water of classes I and II. Regarding to water hardness, the lagoon samples were very hard $\left(372 \mathrm{mg} \mathrm{L}^{-1}\right)$, with high level of chloride $\left(7.4 \mathrm{~g} \mathrm{~L}^{-1}\right)$ due to the less influence of ocean currents as compared with Mundaú Lagoon. This ecosystem presented low level of TOC $\left(1.0 \mathrm{mg} \mathrm{L}^{-1}\right)$, typical from regions of low anthropic influence, and also low levels of NOM in terms of humic substances. On the other side, although the ocurrence of contamination around some sampling points was identified, these TOC data can be justified by the effect of dilution related to the wide extension of Manguaba Lagoon, as well as the smallest number of cities and population living nearby as compared to Mundaú Lagoon.

\section{Metal contents in Manguaba Lagoon samples}

Comprehension of metals distribution and availability in estuaries is essential for preservation of these ecosystems, 
checking anthropic influence and implementation of legislation to preserve the environment. ${ }^{27}$ Therefore, the total concentrations of each metal were determined in the samples of water, sediments and biota from the Manguaba Lagoon and humic substances extracted from waters (AHS) and sediment (SHS), once these kinds of matter play an essential role in the retention of potentially toxic species. In rivers, HS acts mainly as complexing agents avoiding the availability of many species to aquatic environment. ${ }^{27,28}$

\section{Metals in water samples and AHS}

The results of metal concentrations in water samples were established as means of triplicate of sampling points and their respective standard deviation values (Table 4). Among the determined elements, the Brazilian legislation ${ }^{26}$ does not establish maximum limits for $\mathrm{Ca}, \mathrm{Mg}$ and $\mathrm{Mo}$ in brackish waters of classes I and II. The elements $\mathrm{Cr}, \mathrm{Cd}$ and Mo were not detected in any sample, characterizing a positive feature in the matter of water quality.

Table 4. Metal concentrations in water and AHS samples from Manguaba Lagoon

\begin{tabular}{lccc}
\hline & \multicolumn{3}{c}{ Concentration / $\left(\mathrm{mg} \mathrm{L}^{-1}\right)$} \\
\cline { 2 - 4 } Analyte & Water & AHS & $\begin{array}{c}\text { CONAMA } \\
\text { No. 357/2005 }\end{array}$ \\
\hline Ca-II & $32.0 \pm 0.10$ & $12.0 \pm 0.10$ & na \\
Mg-I & $89.0 \pm 0.11$ & $38.0 \pm 0.12$ & na \\
Cd-II & $<$ LOQ & $<$ LOQ & 0.005 \\
Pb-II & $0.22 \pm 0.02$ & $0.18 \pm 0.01$ & 0.01 \\
Cr-II & $<$ LOQ & $<$ LOQ & 0.05 \\
Fe-II & $0.97 \pm 0.02$ & $1.48 \pm 0.03$ & 0.3 \\
Mn-II & $0.52 \pm 0.01$ & $0.77 \pm 0.01$ & 0.1 \\
Mo-II & $<$ LOQ & $<$ LOQ & na \\
Zn-II & $0.33 \pm 0.10$ & $0.63 \pm 0.10$ & 0.09 \\
\hline
\end{tabular}

a Maximum limit established for brackish water of classes I and II by National Council for the Environment (CONAMA, Brazil) Resolution No. 357/2005. ${ }^{26}$ AHS: aquatic humic substance; I and II: classes denoted for atomic line and for ionic line, respectively; na: not assigned; limits of quantification (LOQ): Cd 0.002, Cr 0.05 and Mo $0.05 \mathrm{mg} \mathrm{L}^{-1}$.

The concentration order of metals in water of the explored area in this study was as follows: $\mathrm{Mg}>\mathrm{Ca}>\mathrm{Fe}>$ $\mathrm{Mn}>\mathrm{Zn}>\mathrm{Pb}$. Among these elements, $\mathrm{Ca}$ and $\mathrm{Mg}$ had the highest concentrations in both water and AHS samples. The concentrations of $\mathrm{Zn}, \mathrm{Mn}, \mathrm{Fe}$ and $\mathrm{Pb}$ exceeded the maximum limits for brackish waters of classes I and II by CONAMA $^{26}$ (Table 4), and thus, the population who lives near the sampling points and makes use of the lagoon water for entertainment, bathing and food consumption, is subjected to risks of contamination by these elements, especially $\mathrm{Pb}$ due to its toxic and bioaccumulation potential. ${ }^{29}$

By comparing metal contents in water and AHS from the lagoon taking into account only the factor of concentration of the elements related to AHS extraction procedure, it was expected that all elements had higher concentrations in AHS than in water. However, it must be considered the effect of solubility equilibria of the elements, as well as the complexing capacity of metallic ions by AHS..$^{30}$

The complexing capacity of humic substances reflects the maximum affinity between natural ligands (humic substances) and metalic ions. Studies reveal that exists high affinity of HS by PTM and an exchange equilibrium, generally occurs releasing of nutrients $(\mathrm{Ca}$, $\mathrm{Mg})$ and retention of PTM $(\mathrm{Pb}, \mathrm{Zn})$, corroborating with our results. ${ }^{31,32}$ Moreover, this affinity is a consequence of organic matter features such as the content and characteristics of functional groups of its structure resulted from decomposition of animal and vegetal residues. . $^{31,32}$

The results of metal contents (Table 4) show that in the case of $\mathrm{Ca}$ and $\mathrm{Mg}$, the major concentration in water related to AHS can be due the high hardness of water, so that the solubility equilibria of their respective carbonates may had been shifted to the dissociation of the salts.

\section{Metals in sediment and SHS}

The metal determination in sediments and SHS was done in triplicate at each sampling point. The results of metals in sediment and SHS are presented as concentration ranges due to the wide variability of analytes distribution in the extension of Manguaba Lagoon (Table 5). All sediment data were according to the limits established by CONAMA Resolution No. 420/0933 (Brazilian legislation for soil) and the average concentrations were as follows: $\mathrm{Fe}>\mathrm{Mg}>\mathrm{Ca}>\mathrm{Cr}>\mathrm{Pb}$. These results are similar to the obtained by Botero et al. ${ }^{34}$ as $\mathrm{Pb}$ content was lower and $\mathrm{Fe}$ was higher in sediments of Niquin River (Alagoas State, Brazil). $\mathrm{Ca}$ and $\mathrm{Mg}$ concentrations in sediment and SHS samples were high, considering the very hard water samples analyzed by Wanderley et al. ${ }^{16}$ and the equilibrium in the interface sediment/water. Levels of Cd, $\mathrm{Mn}, \mathrm{Mo}$ and $\mathrm{Zn}$ were below the limit of quantification in all samples, except for Mo which was present in SHS.

Concentrations of $\mathrm{Fe}$ in sediment had a very heterogeneous distribution among the seven sampling points with a range from 1199 to $60000 \mathrm{mg} \mathrm{kg}^{-1}$. This variability can be associated to the anthropic action around the lagoon and evident contribution of contaminants.

In general, metal concentrations were higher in humic substances than in sediment probably due to the pre- 
Table 5. Concentration ranges of metals in sediment and SHS samples from Manguaba Lagoon

\begin{tabular}{lccc}
\hline & \multicolumn{3}{c}{ Concentration range $/\left(\mathrm{mg} \mathrm{kg}^{-1}\right)$} \\
\cline { 2 - 4 } Analyte & Sediment & SHS & $\begin{array}{c}\text { CONAMA } \\
\text { No. } 420 / 09^{\mathrm{a}}\end{array}$ \\
\hline Ca-II & $461-3838$ & $1108-5104$ & na \\
Mg-I & $339-8870$ & $538-14160$ & na \\
Cd-II & $<$ LOQ & $<$ LOQ & 1.3 \\
Pb-II & $<$ LOQ-12.5 & $64.8-77.2$ & 72.0 \\
Cr-II & $<$ LOQ-39.5 & $8.8-33.6$ & 75.0 \\
Fe-II & $1199-60000$ & $4696-13636$ & na \\
Mn-II & $<$ LOQ & $<$ LOQ & na \\
Mo-II & $<$ LOQ & $20.8-68.0$ & 30.0 \\
Zn-II & $<$ LOQ & $<$ LOQ & 300.0 \\
\hline
\end{tabular}

${ }^{a}$ Maximum limit established for brackish water of classes I and II by National Council for the Environment (CONAMA, Brazil) Resolution No. 420/2009. ${ }^{33}$ SHS: sediment humic substances; I and II: classes denoted for atomic line and for ionic line, respectively; na: not assigned; limits of quantification (LOQ): $\mathrm{Cd} 0.002, \mathrm{~Pb} 0.026, \mathrm{Cr} 0.002$, Mn 0.002, Mo 0.038 and $\mathrm{Zn} 0.106 \mathrm{mg} \mathrm{kg}^{-1}$.

concentration of these analytes in the extraction step before their determination.

Humic substances play an essential role in the availability of contaminants in the environment as such matters can retain toxic metals which become unavailable for absorption in aquatic medium. Results of this study evidence high retention of evaluated metals in SHS in agreement with results in the literature. ${ }^{34-36}$

Botero et al..$^{34}$ showed that different affinities to metals are concerning humic substances characteristics related to the decomposition and humification process.

Silva et al. ${ }^{37}$ evaluated hydrocarbons accumulation in sediments of MMELS and observed that Manguaba Lagoon was unpolluted but contaminated, and this contamination was mainly raised from natural inputs.

\section{Metals in biota}

A pooled sample of Tagelus plebeius was analyzed and the results in Figure 2 show the metals present in the mollusk tissue. $\mathrm{Ca}$ was at high concentration as $\mathrm{CaCO}_{3}$ is the main constituent of mollusk shells. ${ }^{38}$ This bivalve can be used as a bioindicator of aquatic ecosystems pollution such as the Manguaba Lagoon because of its wide distribution in this environment. In the extension of the lagoon, the Tagelus plebeius is remarkable for its abundance, easy collection and also for a stationary behavior. The main contaminants determined in this study $(\mathrm{Cr}, \mathrm{Cd}$ and $\mathrm{Pb})$ were below the limit of quantification of the method. This is a result similar to a previous study performed by Lino et al. ${ }^{39}$ that evaluated bivalve organisms in the southeast of the Brazilian coast, in terms of Guanabara and Ilha Grande bays (located at Rio de Janeiro State).

Among the elements evaluated in Tagelus plebeius samples, the maximum limits of inorganic compounds in food, established by the National Sanitary Surveillance Agency (ANVISA), ${ }^{40}$ are 1.5 and $2.0 \mathrm{mg} \mathrm{kg}^{-1}$, for $\mathrm{Pb}$ and $\mathrm{Cd}$, respectively, for bivalve mollusk. However, for the elements present in the mollusk samples (Figure 2), there is no limit established by Brazilian legislation.

Therefore, the results of the present work for biota have a positive aspect regarding to food safety related to the consumption of Tagelus plebeius once this mollusk, to which there is a low commercial value aggregated in the Alagoas State, is widely consumed by the population who lives around the Manguaba Lagoon for their subsistence.

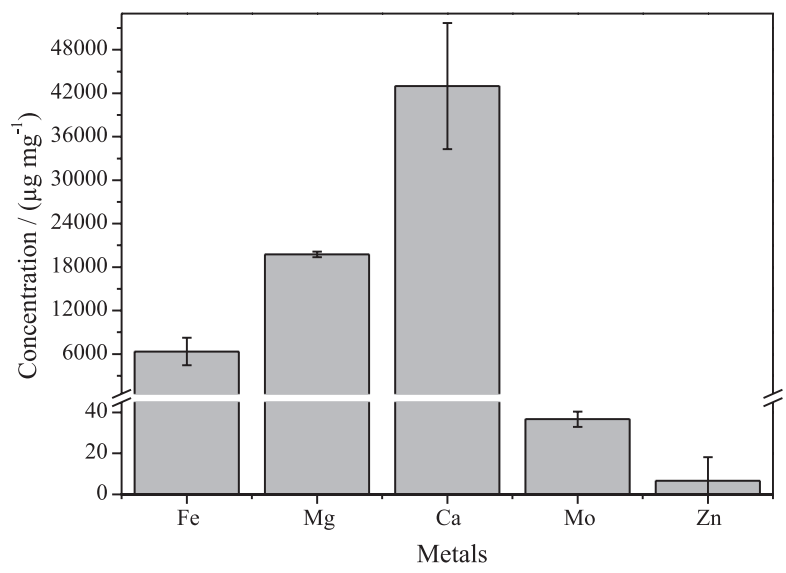

Figure 2. Concentration of metals present in Tagelus plebeius mollusk samples from Manguaba Lagoon.

\section{Figures of merit}

The certified and obtained values, intervals of confidence $(n=3)$ and the recoveries for the metals determined in this study are presented in Table 6 . According to the statistical analysis of the results presented in Table 6, the proposed method is accurate for a confidence level of 95\%. The precision was expressed as relative standard deviation (RSD, $n=3$ ), and the values were below $1 \%$ for all elements and all coefficient of determination $\left(\mathrm{R}^{2}\right)$ were above 0.9978 .

\section{Correlation of metals in the samples of water, sediment and} biota of the Manguaba Lagoon

The relationships among metal concentrations in water, sediment and mollusk depend on factors such as urban and industrial development around the Manguaba Lagoon, which can be contamination sources, besides sanitary 
challenges like drain of untreated sewages. Especially for bioaccumulation in aquatic biota, alimentary customs,

Table 6. Metal concentrations determined in certified reference materials of sediment and mollusk by ICP OES

\begin{tabular}{|c|c|c|c|}
\hline Element & Obtained value & Certified value & Recovery / \% \\
\hline \multicolumn{4}{|c|}{ Standard reference material of estuarine sediment (SRM 1646a) } \\
\hline $\mathrm{Ca} / \%$ & $0.533 \pm 0.020$ & $0.519 \pm 0.020$ & 103 \\
\hline $\mathrm{Fe} / \%$ & $2.367 \pm 0.084$ & $2.008 \pm 0.039$ & 118 \\
\hline $\mathrm{Mg} / \%$ & $0.370 \pm 0.036$ & $0.388 \pm 0.009$ & 95 \\
\hline $\mathrm{Mn} /\left(\mathrm{mg} \mathrm{kg}^{-1}\right)$ & $237.3 \pm 10.8$ & $234.5 \pm 2.8$ & 101 \\
\hline $\mathrm{Pb} /\left(\mathrm{mg} \mathrm{kg}^{-1}\right)$ & $8.3 \pm 1.3$ & $11.7 \pm 1.2$ & 71 \\
\hline $\mathrm{Zn} /\left(\mathrm{mg} \mathrm{kg}^{-1}\right)$ & $47.5 \pm 0.6$ & $48.9 \pm 1.6$ & 97 \\
\hline $\mathrm{Cd} /\left(\mathrm{mg} \mathrm{kg}^{-1}\right)$ & $<0.002$ & $0.148 \pm 0.007$ & nd \\
\hline $\mathrm{Cr} /\left(\mathrm{mg} \mathrm{kg}^{-1}\right)$ & $38.9 \pm 2.4$ & $40.9 \pm 1.9$ & 95 \\
\hline \multicolumn{4}{|c|}{ Certified reference material of Green River Shale (SGR-1) } \\
\hline $\mathrm{Mo} /\left(\mathrm{mg} \mathrm{kg}^{-1}\right)$ & $39 \pm 2.5$ & $35 \pm 0.9$ & 111 \\
\hline $\mathrm{Mn} /\left(\mathrm{mg} \mathrm{kg}^{-1}\right)$ & $240 \pm 11$ & $267 \pm 34$ & 90 \\
\hline \multicolumn{4}{|c|}{ Standard reference material of oyster tissue (SRM 1566b) } \\
\hline $\mathrm{Cd} /\left(\mathrm{mg} \mathrm{kg}^{-1}\right)$ & $2.21 \pm 0.09$ & $2.48 \pm 0.08$ & 89 \\
\hline $\mathrm{Fe} /\left(\mathrm{mg} \mathrm{kg}^{-1}\right)$ & $192.2 \pm 6.7$ & $205.8 \pm 6.8$ & 93 \\
\hline $\mathrm{Mn} /\left(\mathrm{mg} \mathrm{kg}^{-1}\right)$ & $17.3 \pm 0.6$ & $18.5 \pm 0.2$ & 94 \\
\hline $\mathrm{Zn} /\left(\mathrm{mg} \mathrm{kg}^{-1}\right)$ & $1390 \pm 22$ & $1424 \pm 46$ & 98 \\
\hline
\end{tabular}

ICP OES: inductively coupled plasma optical emission spectrometry; nd: not determined. age and growth rate of the organism must be considered, in addition to the bioavailability of metals which varies according to its chemistry identity and concentration.

By comparing the results for metals in water and sediment samples of the present work with data of other Brazilian coastal ecosystems and other continents (Table 7), it was found a high level of $\mathrm{Pb}$ contamination in the Manguaba Lagoon water which was also above the maximum limit of potability established by Brazilian legislation. ${ }^{26}$ These data revealed that the anthropic impact of natural water contaminations by $\mathrm{Pb}$ highlights in Manguaba Lagoon. For $\mathrm{Cd}$ and $\mathrm{Cr}$, in most studies presented in Table 7, these analytes were determined only in sediment, and in general, there was a great variability in the distribution of data along the sampling points of each aquatic ecosystem explored, which is represented by the wide concentration ranges found. According to Table 7, it was also verified that PTM present in the Manguaba Lagoon had comparable concentrations on a basis of the ranges found in samples from other Brazilian aquatic ecosystems. On the other side, by comparing our results with data from different countries, the latter showed evident levels of contamination, based on Brazilian legislation, which may be associated to contamination sources in the respective sampling sites of these countries.

The higher metal concentrations in sediment relative to the water samples of the Manguaba Lagoon showed

Table 7. Comparison between $\mathrm{Pb}, \mathrm{Cd}$ and $\mathrm{Cr}$ concentrations in water and sediment samples from different coastal environments and Manguaba Lagoon

\begin{tabular}{|c|c|c|c|c|c|c|c|}
\hline \multirow{3}{*}{ Local / country } & \multicolumn{6}{|c|}{ Analyte } & \multirow{3}{*}{ Reference } \\
\hline & \multicolumn{2}{|c|}{$\mathrm{Pb}$} & \multicolumn{2}{|c|}{$\mathrm{Cd}$} & \multicolumn{2}{|c|}{$\mathrm{Cr}$} & \\
\hline & $\begin{array}{l}\text { Water / } \\
\left(\mathrm{mg} \mathrm{L}^{-1}\right)\end{array}$ & $\begin{array}{l}\text { Sediment / } \\
\left(\mu \mathrm{g} \mathrm{g}^{-1}\right)\end{array}$ & $\begin{array}{l}\text { Water / } \\
\left(\mathrm{mg} \mathrm{L}^{-1}\right)\end{array}$ & $\begin{array}{l}\text { Sediment / } \\
\left(\mu \mathrm{g} \mathrm{g}^{-1}\right)\end{array}$ & $\begin{array}{l}\text { Water / } \\
\left(\mathrm{mg} \mathrm{L}^{-1}\right)\end{array}$ & $\begin{array}{l}\text { Sediment / } \\
\left(\mu \mathrm{g} \mathrm{g}^{-1}\right)\end{array}$ & \\
\hline Mumbuca Stream, MG / Brazil & $<$ LOD-0.022 & na & na & na & $<$ LOD-0.06 & na & Morais et al..$^{41}$ \\
\hline São Vicente Estuary, SP / Brazil & na & $1.29-48.19$ & na & na & na & $2.75-40.23$ & Kim et al. ${ }^{42}$ \\
\hline Furo de Laura Estuary, AM / Brazil & na & na & na & $2.7-5.2$ & na & $42.3-71.4$ & Lima et al..$^{43}$ \\
\hline Mangrooves, SP / Brazil & $0.10-0.18$ & $4.56-10.33$ & $<0.01$ & $0.053-0.1$ & $<0.05$ & $3.17-7.07$ & Banci et al. ${ }^{44}$ \\
\hline Imboassica Lagoon, SE / Brazil & na & $14-29$ & na & $0.23-2.2$ & na & na & Beraldi et $a{ }^{45}$ \\
\hline Peruíbe (Guaraú), SP /Brazil & na & $3.0-17.6$ & na & $0.0-2.1$ & na & $4.2-37.3$ & Moreira et al. ${ }^{46}$ \\
\hline Rodrigo de Freitas Lagoon, RJ / Brazil & na & $6-122$ & na & $<0.8$ & na & $3-56$ & Vezzone et al. ${ }^{2}$ \\
\hline Rodrigo de Freitas Lagoon, RJ / Brazil & na & $37-103$ & na & $1.1-2.1$ & na & $3-74$ & Vezzone et al..$^{2}$ \\
\hline Mandovi Estuary / India & na & $23-28$ & na & na & na & $146-150$ & $\begin{array}{l}\text { Veerasingam } \\
\text { et al. } .^{47}\end{array}$ \\
\hline Manzala Lake / Egypt & $0.032-0.048$ & $0.21-0.31$ & $0.002-0.005$ & $0.02-0.032$ & na & na & Gawad $^{29}$ \\
\hline Cau Hai Lagoon / Vietnam & na & $23-53$ & na & $0.2-0.4$ & na & $44-98$ & Tran et al. ${ }^{48}$ \\
\hline Rabigh Lagoon / Saudi Arabia & na & $133-288$ & na & 4.4-20.1 & na & $6.6-15.0$ & Aljahdali et al..$^{3}$ \\
\hline $\begin{array}{l}\text { Mangroove of Khung Bay Krabaen / } \\
\text { Thailand }\end{array}$ & na & $4.9-9.2$ & na & na & na & $7.4-22.1$ & Hong et al. ${ }^{49}$ \\
\hline Manguaba Lagoon, AL / Brazil & 0.22 & $<$ LOQ-12.5 & $<$ LOQ & $<\mathrm{LOQ}$ & $<\mathrm{LOQ}$ & $<$ LOQ-39.5 & this study \\
\hline
\end{tabular}

LOD: limit of detection; na: not assigned; limits of quantification (LOQ) of this study: $\mathrm{Pb} 0.026, \mathrm{Cd} 0.002$ and $\mathrm{Cr} 0.002 \mathrm{mg} \mathrm{kg}^{-1}$. 

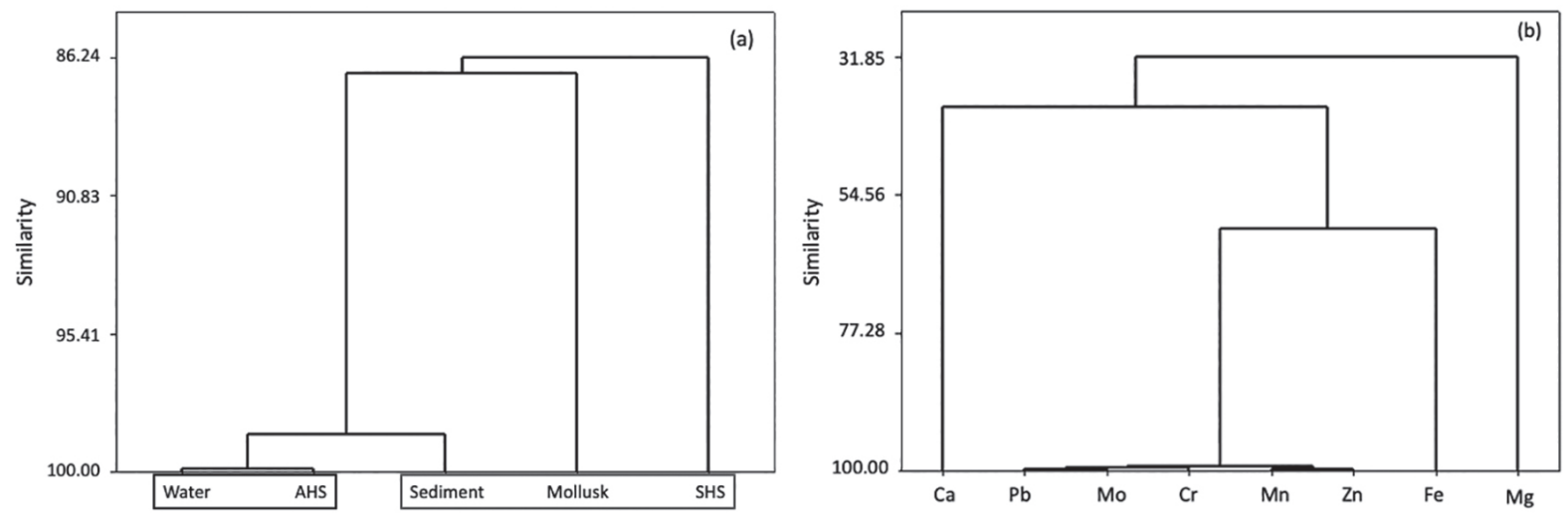

Figure 3. Dendrogram obtained by hierarchical cluster analysis (HCA) of metals in the studied environmental samples of the Manguaba Lagoon: (a) sample and (b) metal similarities.

the accumulation capacity of sediment related to water. Moreover, bivalve mollusks, known filtering organisms that live inside the sediment, such as Tagelus plebeius, are capable of bioaccumulate metals and transport them through the food chain. However, the obtained data for PTM like $\mathrm{Pb}$ in the mollusk lower than the LOQ did not seem to disturb the environmental equilibrium of the Manguaba Lagoon ecosystem.

The low $\mathrm{Pb}$ concentration in marine organisms, in general, is due to the minor bioavailability of this ion dissolved and inserted in the food chain of biota, and even in contaminated areas, the $\mathrm{Pb}$ bioaccumulation in some bivalves is slow. ${ }^{50}$

\section{Multivariate statistical analysis}

The statistic relationship among the environmental samples evaluated in this study on a basis of metal levels $(\mathrm{Ca}, \mathrm{Mg}, \mathrm{Pb}, \mathrm{Cr}, \mathrm{Cd}, \mathrm{Mo}, \mathrm{Zn}, \mathrm{Fe}$ and $\mathrm{Mn}$ ) was established by HCA to auxilliary a multivariate interpretation of data (Figures $3 a$ and $3 b$ ).

The hierarchical analysis is characterized by formation of natural clusters in a hierarchical structure wherein samples are placed in a system of groups and subgroups depending on the degree of similarity between them.

Figure 3 a shows the formation of a cluster with similarity of $99.2 \%$ between water and AHS emphasizing the difference of this compartment in relation to the others evaluated for metal contents. Studies ${ }^{51}$ show that aquatic humic substances have higher levels of fulvic acids and differences in functional groups. In addition, as the water is renewed in this estuarine system, an organic matter is observed with more recent characteristics similar to water samples. ${ }^{16}$

It is also observed that in whole general the similarity among all evaluated kinds of samples is about $86 \%$, showing the close and important relationship among them.

Concerning to the similarity among the evaluated metals
(Figure 3b), it can be observed that $\mathrm{Ca}, \mathrm{Fe}$ and $\mathrm{Mg}$ differ from the others due to the high concentrations of these analytes in all environmental samples.

These results show the close relationship among all environmental samples explored in this study (water, AHS, sediment, SHS and mollusk) and the need to make this assessment in order to have a better understanding of the availability mechanisms of metals in estuarine systems, and thus, to develop strategies for preservation of this ecosystem.

\section{Conclusions}

The distribution profile of metals in the environmental samples of the Manguaba Lagoon was established based on samples of water, AHS, sediment, SHS and mollusk from the lagoon extension. According to the high correlation obtained by HCA analysis, it can be inferred that a contamination with at least one of the determined metals would cause deleterious effects in both compartments (water and sediment) even in presence of humic substances, that are capable of diminish the availability of PTM as can retain these elements in surfaces. Among the elements determined, the high $\mathrm{Pb}$ concentrations in water are of concern in relation to the health and food security of the populations living around the lagoon.

\section{Acknowledgments}

The authors wish to acknowledge the provision of CAPES, FAPEAL, CNPq and Institute of Chemistry and Biotechnology of UFAL for financial support, scholarships and infrastructure waived for execution of experiments.

\section{References}

1. Rosa, L. M. T.; Botero, W. G.; Santos, J. C. C.; Cacuro, T. A.; Waldman, W. R.; do Carmo, J. B.; Oliveira, L. C.; J. Environ. Manage. 2015, 215, 91. 
2. Vezzone, M.; Cesar, R.; Abessa, D. M. S.; Serrano, A.; Lourenço, R.; Castilhos, Z.; Rodrigues, A. P.; Perina, F. C.; Polivanov, H.; Environ. Pollut. 2019, 252, 270.

3. Aljahdali, M. O.; Alhassan, A. B.; Saudi J. Biol. Sci. 2020, 27, 1174.

4. Li, Z.; Wang, P.; Menzies, N. W.; Kopittke, P. M.; Ecotoxicol. Environ. Saf. 2018, 147, 872.

5. Khan, A.; Khan, S.; Alam, M.; Khan, M. A.; Aamir, M.; Qamar, Z.; Rehman, Z. U.; Perveen, S.; Chemosphere 2016, 146, 121.

6. Rahimzadeh, M. R.; Rahimzadeh, M. R.; Kazemi, S.; Moghadamnia, A.; Caspian J. Int. Med. 2017, 8, 135.

7. DesMarias, T. L.; Costa, M.; Curr. Opin. Toxicol. 2019, 14, 1.

8. Boskabady, M.; Marefati, N.; Farkhondeh, T.; Shakeri, F.; Farshbaf, A.; Boskabady, M. H.; Environ. Int. 2018, 120, 404.

9. Rebelo, F. M.; Caldas, E. D.; Environ. Res. 2016, 151, 671.

10. World Health Organization (WHO); Childhood Lead Poisoning, 2010, available at https://apps.who.int/iris/bitstream/ handle/10665/136571/9789241500333_eng.pdf;jsessionid= 77716FBC86AFC76E46C9E08DAA35D98D? sequence $=1$, accessed in October 2020.

11. Ding, H.; Tang, L.; Nie, Y.; Ji, H.; J. Geochem. Explor. 2019, $200,266$.

12. Dou, S.; Shan, J.; Song, X.; Cao, R.; Wu, M.; Li, C.; Guan, S.; Pedosphere 2020, 30, 159.

13. Lipczynska-Kochany, E.; Chemosphere 2018, 202, 420.

14. Ministério do Meio Ambiente, Agência Nacional de Águas (ANA); Plano de Ações e Gestão Integrada do Complexo Estuarino Lagunar Mundaú-Mangaba (CELMM): Resumo Executivo, 2006, p. 124, available at http://arquivos.ana.gov. br/institucional/sge/CEDOC/Catalogo/2006/CELMM.pdf, accessed in October 2020.

15. Jacundino, J. S.; Santos, O. S.; Santos, J. C. C.; Botero, W. G.; Goveia, D.; do Carmo, J. B.; de Oliveira, L. C.; J. Environ. Chem. Eng. 2015, 3, 708.

16. Wanderley, A. D. P.; Mendonça, A. G. R.; de Oliveira, L. C.; Figueiredo, I. M.; Fernandes, A. P.; Batalha, L. T.; Botero, W. G.; Quim. Nova 2020, 43, 206.

17. Junior, S. A. M. G.; do Nascimento, M. C.; da Silva, D. J. R. P.; Rev. Contexto Geogr. 2017, $2,86$.

18. Lira, G. M.; Torres, E. A. F. S.; Soares, R. A. M.; Mendonça, S.; Costa, M. F.; Silva, K. W. B.; Simon, S. J. G. B.; Veras, K. M. A.; Rev. Inst. Adolfo Lutz 2007, 66, 261.

19. Maioli, O. L. G.; Rodrigues, K. C.; Knoppers, B. A.; Azevedo, D. A.; Microchem. J. 2010, 96, 172.

20. Garcia, K. S. In Técnicas de Campo e Laboratório Aplicadas às Matrizes dos Ambientes Costeiros nos Municípios de Una, Canavieiras e Belmonte; Garcia, K. S.; Celino, J. J., eds.; EDUFBA: Salvador-BA, Brazil, 2014, p. 40.

21. International Humic Substances Society (IHSS); Isolation of IHSS Samples, available at https://humic-substances.org/ isolation-of-ihss-samples/, accessed in October 2020.
22. United States Environmental Protection Agency (EPA); Method 3015A: Microwave Assisted Acid Digestion of Aqueous Samples and Extracts, available at https://www.epa.gov/sites/ production/files/2015-12/documents/3015a.pdf, accessed in October 2020.

23. United States Environmental Protection Agency (EPA); Method 3052: Microwave Assisted Acid Digestion of Siliceous and Organically Based Matrices, available at https://www.epa.gov/ sites/production/files/2015-12/documents/3052.pdf, accessed in October 2020.

24. International Union of Pure and Applied Chemistry (IUPAC); Compendium of Chemical Terminology, The "Gold Book", $2^{\text {nd }}$ ed.; McNaught, A. D.; Wilkinson, A., eds; Blackwell Scientific Publications: Oxford, 1997, available at https://goldbook.iupac. org/terms/view/C00858, accessed in October 2020.

25. Minitab 14; Minitab Inc., State College, PA, USA, 2014.

26. Conselho Nacional do Meio Ambiente (CONAMA), Resolution No. 357/2005, available at http://www2.mma.gov.br/port/ conama/legiabre.cfm?codlegi=459, accessed in October 2020.

27. Cindric, A.; Marcinek, S.; Garnier, C.; Salaün, P.; Cukrov, N.; Oursel, B.; Lenoble, V.; Omanovic, D.; Sci. Total Environ. 2020, 721,137784

28. Mudhoo, A.; Ramasamy, D. L.; Bhatnagar, A.; Usman, M.; Sillanpää, M.; Ecotoxicol. Environ. Saf. 2020, 197, 110587.

29. Gawad, S. S. A.; Egypt. J. Aquat. Res. 2018, 44, 77.

30. Wang, X.; Muhmood, A.; Dong, R.; Wu, S.; J. Cleaner Prod. 2020, 255, 120243.

31. Swift, R. S. In Methods of Soil Analysis. Part 3. Chemical Methods; Sparks, D. L.; Page, A. L.; Helmke, P. A.; Soltanpour, P. N.; Tabatabai, M. A.; Johnston, C. T.; Sumner, M. E., eds.; Soil Science Society of America: Madison, WI, USA, 1996, ch. 35.

32. Botero, W. G.; de Oliveira; L. C.; Rocha, J. C.; Rosa, A. H.; dos Santos, A.; J. Hazard. Mater. 2010, 177, 307.

33. Conselho Nacional do Meio Ambiente (CONAMA), Resolution No. 420/2009, available at http://www2.mma.gov.br/port/ conama/legiabre.cfm?codlegi=620, accessed in October 2020.

34. Botero, W. G.; Souza, S. O.; Santos, O. S.; de Oliveira, L. C.; do Amarante, C. B.; Quim. Nova 2014, 37, 943.

35. Giovanela, M.; Crespo, J. S.; Antunes, M.; Adamatti, D. S.; Fernandes, A. N.; Barison, A.; da Silva, C. W. P.; Guégan, R.; Motelica-Heino, M.; Sierra, M. M. D.; J. Mol. Struct. 2010, 981,111

36. Neto, L. M.; Andriulo, A. E.; Traghetta, D. G.; Soil Sci. 1994, 157,365 .

37. Silva, T. R.; Lopes, S. R. P.; Spörl, G.; Knoppers, B. A.; Azevedo, D. A.; Microchem. J. 2013, 109, 178.

38. Dar, M. A.; Belal, A. A.; Madkour, A. G.; Egypt. J. Aquat. Res. 2018, 44, 298.

39. Lino, A. S.; Galvão, P. M. A.; Longo, R. T. L.; Azevedo-Silva, C. E.; Dorneles, P. R.; Torres, J. P. M.; Malm, O.; J. Trace Elem. Med. Biol. 2016, 34, 50. 
40. Ministério da Saúde, Agência Nacional de Vigilância Sanitária (ANVISA); Resolução da Diretoria Colegiada (RDC) No. 42, de 29 de agosto de 2013, Dispõe sobre o Regulamento Técnico MERCOSUL sobre Limites Máximos de Contaminantes Inorgânicos em Alimentos, Diário Oficial da União (DOU), Brasília, Brazil, 2013.

41. Morais, C. R.; Carvalho, S. M.; Araujo, G. R.; Souto, H. N.; Bonetti, A. M.; Morelli, S.; Chemosphere 2016, 152, 328.

42. Kim, B. S. M.; Salaroli, A. B.; Ferreira, P. A. L.; Sartoretto, J. R.; de Mahiques, M. M.; Figueira, R. C. L.; Mar. Pollut. Bull. 2016, 103, 333.

43. Lima, M. W.; Santos, M. L. S.; Faial, K. C. F.; Freitas, E. S.; Lima, M. O.; Pereira, J. A. R.; Cunha, I. P. R. T.; Mar. Pollut. Bull. 2017, 118, 403.

44. Banci, K. R. S.; Mori, G. M.; de Oliveira, M. A.; Paganelli, F. L.; Pereira, M. R.; Pinheiro, M. A. A.; Mar. Pollut. Bull. 2017, 116, 440.

45. Beraldi, G. Q. F.; de Rezende, C. E.; de Almeida, M. G.; Carvalho, C.; de Lacerda, L. D.; de Farias, R. N.; Vidal, M.;
Souza, M. D. P.; Molisani, M. M.; Mar. Pollut. Bull. 2019, 146, 552.

46. Moreira, L. B.; Leite, P. R. B. D.; Dias, M. L.; Martins, C. C.; Abessa, D. M. S.; Ecol. Indicators 2019, 101, 238.

47. Veerasingam, S.; Vethamony, P.; Murali, P. M.; Fernandes, B.; Mar. Pollut. Bull. 2015, 91, 362.

48. Tran, T. A. M.; Leermakers, M.; Hoang, T. L.; Nguyen, V. H.; Elskens, M.; Chemosphere 2018, 210, 175.

49. Hong, A. H.; Hargan, K. E.; Williams, B.; Nuangsaeng, B.; Siriwong, S.; Tassaward, P.; Chaiharn, C.; Huertos, M. L.; Ecol. Indicators. 2020, 115, 106365.

50. Riget, F.; Johansen, P.; Asmund, G.; Mar. Pollut. Bull. 1997, 34,805 .

51. Oliveira, L. C.; Botero, W. G.; Santos, F. A.; Sargentini Jr., E.; Rocha, J. C.; Santos, A.; J. Braz. Chem. Soc. 2012, 23, 1711.

Submitted: June 17, 2020

Published online: November 4, 2020 